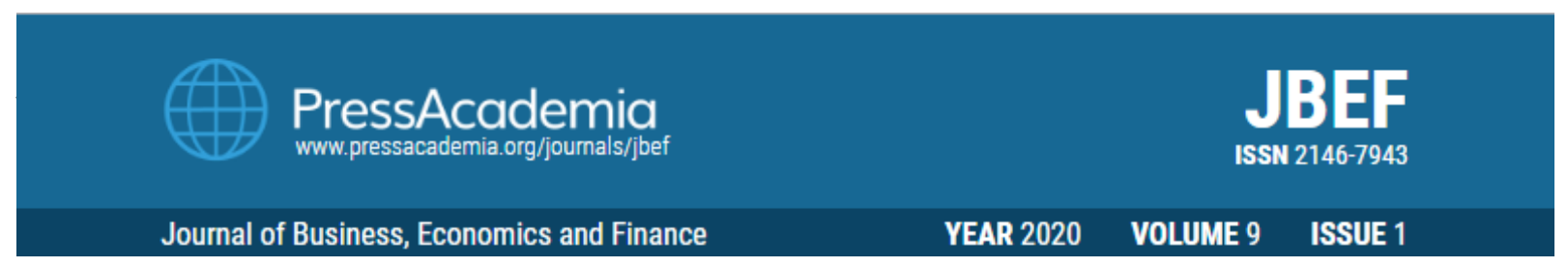

\title{
COMPANY STOCK REACTIONS TO BLACK NOISE TWEETS: EVIDENCE FROM STEEL INDUSTRY
}

\author{
DOI: 10.17261/Pressacademia.2020.1192 \\ JBEF- V.9-ISS.1-2020(5)-p.52-61
}

\section{Caner Ozdurak ${ }^{1}$, Veysel Ulusoy ${ }^{2}$}

${ }^{1}$ Yeditepe University, Department of Financial Economics, Atasehir, Istanbul, Turkey. caner.ozdurak@yeditepe.edu.tr, ORCID: 0000-0003-0793-7480

${ }^{2}$ Yeditepe University, Department of Financial Economics, Atasehir, Istanbul, Turkey. vulusoy@yeditepe.edu.tr, ORCID: 0000-0001-7227-894X

Date Received: February 11, 2020

Date Accepted: March 27, 2020

\section{To cite this document}

Ozdurak, C., Ulusoy, V., (2020). Company stock reactions to black noise tweets: evidence from steel industry. Journal of Business, Economics and Finance (JBEF), V.9(1), p.52-61.

Permemant link to this document: http://doi.org/10.17261/Pressacademia.2020.1192

Copyright: Published by PressAcademia and limited licenced re-use rights only.

\begin{abstract}
Purpose - The purpose of this study is to test the validity of super-fast development of social media and its wide range of use by even professional investors as the new financial contagion which is carried with "Black Noise" tweets. Newly established robotic modern finance environment and various news channels provide the necessary infrastructure to utilize a focused and directed market noise. Measuring the impact of this noise in the financial market volatility is a crucial and important issue.

Methodology - In this study, we investigate the news impact of trade wars and monetary policy news on steel industry of US and its reflection on Turkish markets utilizing 30 minutes high frequency return data. The novelty is this study is the interaction terms that we generated and embedded in the E-GARCH models to test the reactions of steel major listed US steel industry companies such as US Steel, AK Steel, Nucor and the pioneer Turkish company Ereğli in this sector.

Findings- Findings of this study highlights that specific news about trade war and monetary policy have a significant impact on steel company returns. For further research papers testing the speculation strength of such tweet can be a beneficial topic for the other researchers.

Conclusion- As a result of this study, being one the major market makers, Trump's direct messages to the market via Twitter and such, about sanctions, interest rates and monetary policy creates "Black Noise" in financial markets. Even in a durable production industry like steel sector this leads to speculation.
\end{abstract}

Keywords: EGARCH, news impact curves, black noise, tweet, contaign.

JEL Codes: C58, G14, G15

\section{INTRODUCTION}

2008 global financial crisis provides us with a wide range of study field on cross-asset contagion mechanisms in the US financial markets. Contagion in the financial markets was one of the most popular research topics in finance literature triggered by Forbes and Rigobon (2001). After a decade of the so-called subprime crisis the impact of market news on asset volatilities increased significantly.

Especially after the US elections and Trump era started, trade wars and sanctions declared by US decision makers fueled cross-asset contagion. The way in which information is disseminated to the masses has evolved with the introduction of social media platforms. During the 2016 presidential election, candidates used the platform to increase their media coverage, especially Donald Trump. His current position empowers his tweets to influence public sentiment, decisions of financial market actors and even the performance of stock returns.

With the increasing influence of social media which fuels the information spillover, even Bloomberg L.P. is incorporating tweets into its data service, which is widely used in the financial industry. Even two of the largest Wall Street banks are trying to measure the market impact of Donald Trump's tweets. Analysts at JPMorgan Chase \& Co. have created an index to quantify 
what they say are the growing effects on U.S. bond yields. Citigroup Inc.'s foreign exchange team, meanwhile, report that these micro-blogging missives are also becoming "increasingly relevant" to foreign-exchange moves ${ }^{1}$.

The point is Trump's tweets are giving the market whiplash which we define as "Black Noise ${ }^{2}$ " Black noise is a type of noise where the dominant energy level is zero throughout all frequencies, with occasional sudden rises; it is also defined as silence. Contrary to general consideration, sound and silence are not each other's opposite, but they are mutually inclusive. Silence is used as a verb in western languages with the meaning of "causing to become silent, prohibiting or preventing from speaking". In this context, tweets of Trump, who has the market power as the president of global economy and financial markets driving country, creates noise in financial markets while mutually preventing the other actors or indicators from speaking.

Even by the 1980s even reading Wall Street Journal or the availability of watching TV on the trading floor provided significant information advantage. In modern financial markets taken over by algorithms and passive manager the impact of available information spread out by market makers is uncontrollable. The rise of financial robotization both changes the speed and make-up of the stock market and affects the under economy.

However, humans are not out of the picture entirely since they have a very important role of picking and choosing which data to feed in the machine. So, from one point they teach the algorithm what data to look and then manipulate that data by creating noise in the markets. Super-fast development of social media and its wide range of use by even professional investor now financial contagion is carried even with "Black Noise" tweets. As a result, newly established robotic modern finance environment and various news channels provide the necessary infrastructure to utilize a focused and directed market noise.

\section{LITERATURE REVIEW}

Previous literature studies focus on firstly to test whether the contagion exits in financial markets after global financial crisis and secondly improve the weakness of Forbes and Rigobon's (2002) methodology. Most researchers focus on cross-country relationships (e.g. King and Wadhwani, 1990; Kodres and Pritsker; 1998; Kaminsky et al. 2003, Dungey et al., 2007) while Guidolin et. al. (2019) focus on cross-asset contagion mechanism. Based on the results of all these studies we accept that contagion exits in the market. Our aim is to question whether the structure of contagion changed recently especially after Trump election and his utilization of social media as a financial market speculation tool.

In this context, recent studies focus on the impact of social media on financial markets, stock returns and company reactions more and more. Zheludev et. al (2014) showed that social media message sentiment can contain statistically significant exante information on the future prices of the S\&P 500 Index. Tafti et al. (2016) found a spike in tweets per minute resulted in spike in trading activity in the following forty minutes. In their study they evaluate 96 firms on the NASDAQ over 193 trading days which were statistically compared with Yahoo! Finance data of the related firms. Most of the studies focus on the evaluation of message volumes and retrospective evaluation of trading strategy returns. Cove and Sardy (2019) found that Trump tweets have an impact on financial markets even at the level of daily returns. These findings were limited by the nature of daily S\&P 500 returns and there was a gross mismatch between the timing of tweets and daily results. In our study with interaction dummy we were able to more directly see the instantaneous effect of the tweets on the market.

There two types of specific news subjects in this study. Firstly, news about trade wars mainly about sanctions declared by US President to especially China and steel industry is considered. Although export from Turkey does not constitute a significant portion of US import, we also tested the impact of sanction declarations against Turkey via Ereğli stock return volatility models. Jensen (2006) shows that trade dispute over US steel production provides a case to reconsider the role of World Trade Organization (WTO) in settling trade disputes and stabilize the expectations of the market. His study mentions that during the 2002 WTO steel case, the WTO dispute mechanism helped market actors stabilize expectations of future trade policy. In our case Trump's tweets serves quite the opposite of WTO dispute mechanism which does not help the market to stabilize at all. Lo and MacKinlay (1999) argues that stock prices do not fully adjust immediately to new information while Glosten et al. (1993) criticize Efficient Market Hypothesis of Fama (1970) stating that stocks respond asymmetrically to positive and negative news. In our study with interaction dummy variables and using high frequency semi-hourly data we test all these criticisms with relevant volatility models.

Secondly news about monetary policy and FED decisions fueled with the conflicts between Trump and Powell constitutes our second dummy variable.

\footnotetext{
${ }^{1}$ Our preliminary analysis of this article was announced a week before these studies in Turkish Economy channels and reputable economics news websites

2 Black Noise term is inspired by a contemporary art exhibition composed of the works of the artists; Burak Arıkan, Servet Cihangiroğlu, Didem Erk, Richard Jochum, Cengiz Tekin, Anna Vasof, Mirko Lazović.
} 


\section{METHODOLOGY}

One model that allows for asymmetric effect of news is the EGARCH model. One problem with a standard GARCH model is that it is necessary to ensure that all the estimate coefficients are positive. Nelson (1991) proposed a specification that does not require non-negativity constrains.

Consider:

$$
\ln \left(h_{t}\right)=\alpha_{0}+\alpha_{1}\left(\frac{\varepsilon_{t-1}}{h_{t-1}^{0.5}}\right)+\lambda_{1}\left|\frac{\varepsilon_{t-1}}{h_{t-1}^{0.5}}\right|+\beta_{1} \ln \left(h_{t-1}\right)
$$

Equation (3.1) is called the exponential-GARCH or EGARCH model. There are three interesting features to notice about EGARCH model:

1. The equation for the conditional variance is in log-linear form. Regardless of the magnitude of $\ln \left(h_{t}\right)$, the implied value of $h_{t}$ can never be negative. Hence, it is permissible for the coefficients to be negative.

2. Instead of using the value of $\varepsilon_{t-1}^{2}$, the EGARCH model uses the level of standardized value of $\varepsilon_{t-1}^{2}$ [ i.e., $\varepsilon_{t-1}^{2}$ divided by $\left(h_{t-1}\right)^{0.5}$ ]. Nelson argues that this standardization allows for a more natural interpretation of the size and persistence of shocks. After all, the standardized value of $\varepsilon_{t-1}^{2}$ is a unit-free measure.

3. The EGARCH model allows the leverage effects. If $\varepsilon_{t-1}^{2} /\left(h_{t-1}\right)^{0.5}$ is positive, the effect of the shock on the log of conditional variance is $\alpha_{1}+\lambda_{1}$. If $\varepsilon_{t-1}^{2} /\left(h_{t-1}\right)^{0.5}$ is negative, the effect of the shock on the log of the conditional variance is $-\alpha_{1}+\lambda_{1}$.

The trade-off between future risks and asset returns are the essence of most financial decisions. Risk mainly composes of two factors such as volatilities and correlations of financial assets. Since the economy changes frequently and new information is distributed in the markets second moments evolve over-time. Consequently, if methods are not carefully established to update estimates rapidly then volatilities and correlations measured using historical data may not be able to catch differentiation in risk (Cappiello et. all, 2006).

If we consider EGARCH models, the news impact curve has its minimum at $\varepsilon_{\mathrm{t}-1}=0$ and is exponentially increasing in both directions but with different parameters. The news impact curves are made up by using the estimated conditional variances equation for the related model as such the given coefficient estimates and with the lagged conditional variance set to the unconditional variance.

Consider EGARCH $(1,1)$

$$
\ln \left(h_{t}\right)=\alpha_{0}+\beta \ln \left(h_{t-1}\right)+\alpha_{1} z_{t-1}+\gamma\left(\left|z_{t-1}\right|\right)-E\left(\left|z_{t-1}\right|\right)
$$

where $z_{t}=\varepsilon_{t} / \sigma_{t}$. The news impact curve is

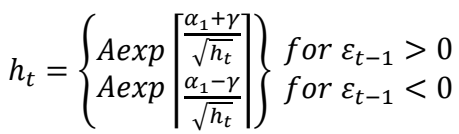

$$
\begin{aligned}
& A \equiv h_{t}^{\beta} \exp \left[\alpha_{0}-\gamma \sqrt{2 / \pi}\right] \\
& \alpha_{1}<0 \quad \alpha_{1}+\gamma>0
\end{aligned}
$$

An important characteristic of asset prices is that "bad" news has more persistent impact on volatility than "good" news has. Most of the stocks has a strong negative correlation between the current return and the future volatility. In this context we can define leverage effect as such volatility tends to decrease when returns increase and to increase when returns decrease.

The idea of the leverage effect is exhibited in the figure below, where "new information" is defined and measured by the size of $\varepsilon_{t-1}$. If $\varepsilon_{t-1}=0$, expected volatility $\left(h_{t}\right)$ is 0 . Actually, any news increases volatility but if the news is "good" (i.e., if $\varepsilon_{t}$ is positive), volatility rises from point $\boldsymbol{a}$ to point $\boldsymbol{b}$ along ab curve (or ab' for EGARCH model). However, if the news is "bad", volatility rises from point $\boldsymbol{a}$ to point $\boldsymbol{c}$ along ac curve (or ac' for EGARCH model). Since ac and ac' are steeper than ab and ab', a positive $\varepsilon_{t}$ shock will have a lower impact on volatility than a negative shock of these same magnitude (Figure 1).

Asymmetric volatility models are the most interesting approaches in the literature since good news and bad news have different predictability for the future volatility. Overall, Chen and Ghysels (2010) found that partly good (intra-daily) news decreases volatility (the next day), while both very good news which is unusual high intra-daily positive returns, and bad news which is negative returns increase volatility. However, the latter has a more severe impact over longer horizons the asymmetries fade away. 
The news impact curve illustrates the impact of previous return shocks on the return volatility which is implicit in a volatility model.

Figure 1: News Impact Curves

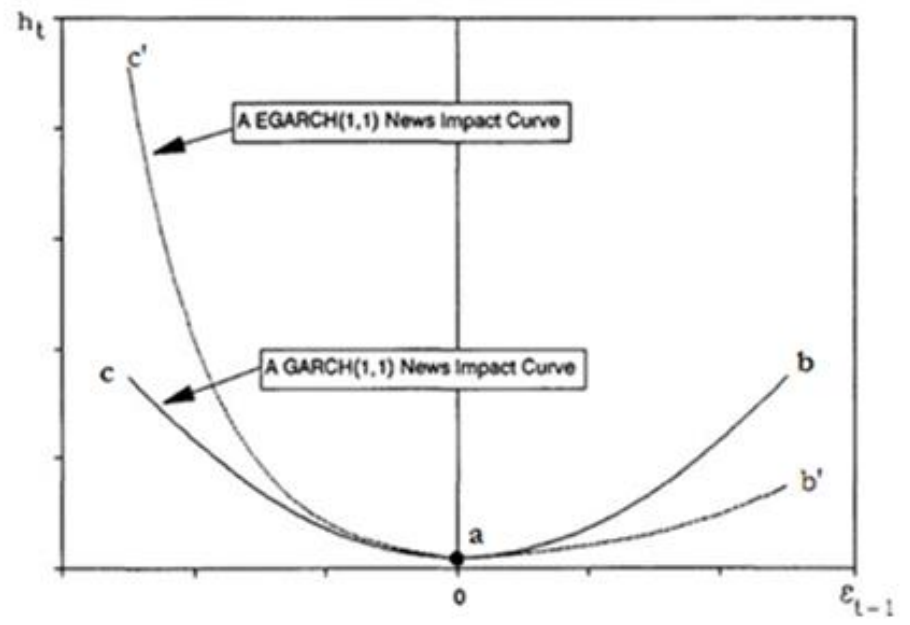

\section{DATA AND PRELIMINARY ANALYSIS}

The study considers semi-hourly closing prices for Crude Oil (CRUDE), S\&P 500 Index (SPX), S\&P Metals and Mining Select Industry Index (SPXSMM), Borsa Istanbul 100 Index (XU100), Borsa Istanbul Industrial Index (XUSIN), AK Steel ${ }^{3}$ (AKSTEEL), US Steel $^{4}$ (USSTEEL), Nucor ${ }^{5}$ (NUCOR) and Ereğli ${ }^{6}$ (EREGLI) stock prices to explore the impact of trade war, monetary policy and FED decision news on the returns and volatility of steel industry. Semi-hourly data for all assets has been taken from Thompson Reuters Eikon. The time span for the study runs from 16 October 2018 to 16 October 2019 based on the availability of trade war, monetary policy and FED decision news. If we briefly describe the selected companies:

AK Steel Holding Corporation (AK Steel) is a producer of flat-rolled carbon, stainless and electrical steels, and tubular products through its subsidiary, AK Steel Corporation (AK Steel).

United States Steel Corporation (US Steel) is an integrated steel producer of flat-rolled and tubular products with major production operations in the United States and Europe

Nucor Corporation (Nucor) manufactures steel and steel products.

Ereğli Demir ve Celik Fabrikalari TAS (Ereğli) is a Turkey-based company, which is engaged in the production of iron and steel rolled products, alloyed and non-alloyed iron, steel and pig iron castings, cast and pressed products, coke and their byproducts

\footnotetext{
${ }^{3}$ The Company also operates blast furnaces and electric arc furnaces. As of December 31, 2016, its operations included eight steelmaking and finishing plants, two coke plants and two tube manufacturing plants. These operations produce flat-rolled carbon, specialty stainless and electrical steels that it sells in sheet and strip form, and carbon and stainless steel that it finishes into welded steel tubing. It also produces metallurgical coal through its subsidiary, AK Coal Resources, Inc. In addition, the Company operates trading companies in Mexico and Europe that buy and sell steel and steel products and other materials.

${ }^{4}$ US. Steel has annual raw steel production capability of 22.0 million net tons $(17.0$ million tons in the United States and 5.0 million tons in Europe). According to World Steel Association's latest published statistics, in 2017 U. S. Steel was the third largest steel producer in the United States and the twenty-sixth largest steel producer in the world.

${ }^{5}$ The Company produces direct reduced iron (DRI) for use in its steel mills. It operates in three segments: steel mills, steel products and raw materials. The steel mills segment produces and distributes sheet steel (hot-rolled, cold-rolled and galvanized), plate steel, structural steel (wide-flange beams, beam blanks, H-piling and sheet piling) and bar steel (blooms, billets, concrete reinforcing bar, merchant bar, wire rod and special bar quality).

${ }^{6}$ The Company produces plates, hot and cold rolled, tin, chromium and zinc coated flat steel and supplies basic inputs to automotive, white goods, pipes and tubes, rolling, manufacturing, electrics-electronics, mechanical engineering, energy, heating equipment, shipbuilding, defense, and packaging industries.
} 
Figure 1: Graphs of Selected Companies vs Industry Indices
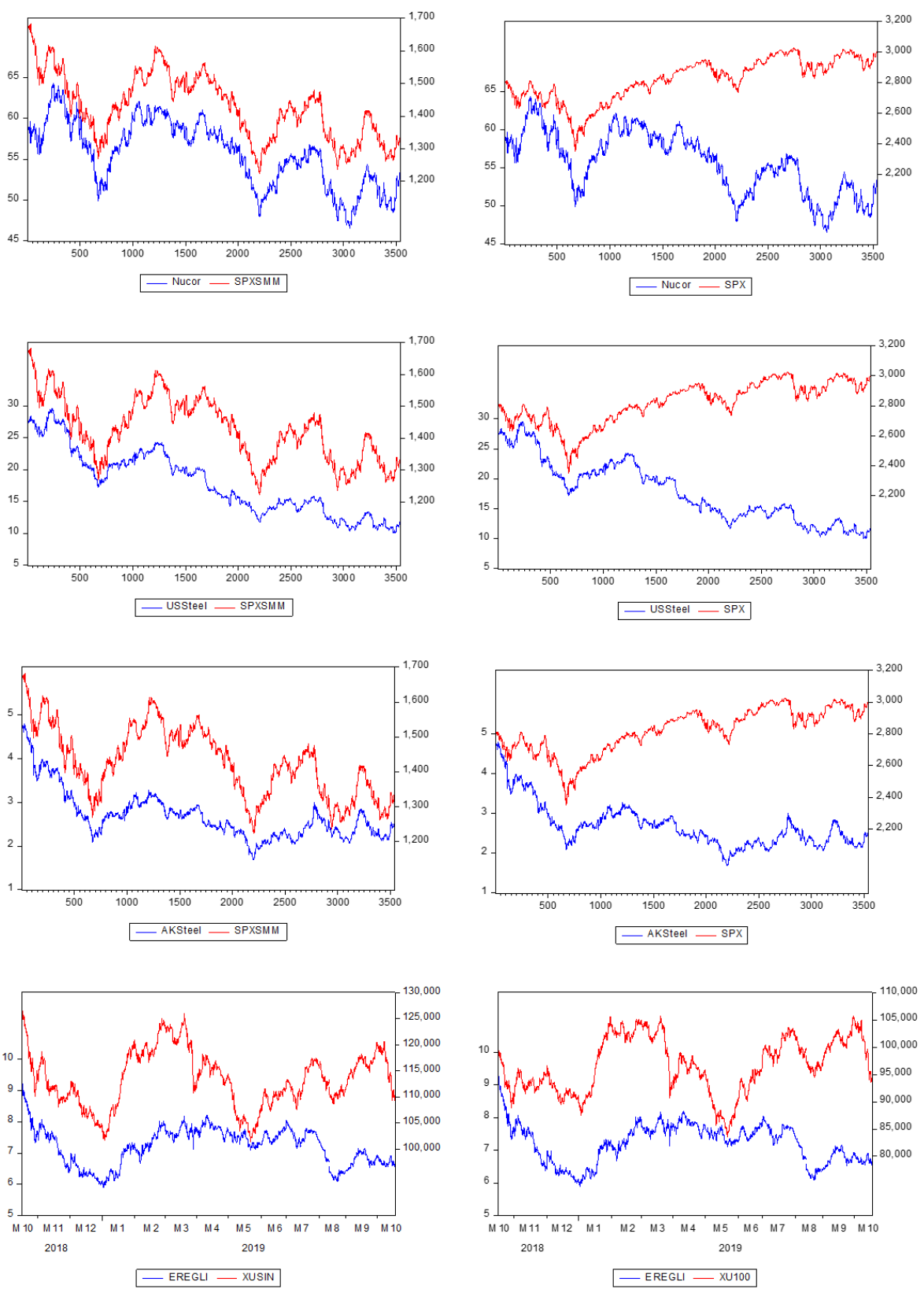

Figure 1 provides plot of selected companies versus industry indices and market indices that they are listed in. The visual inspection of the plot reveals that steel company stocks drives the performance of industry index in US while they diverge from the whole market index time by time. However, in Turkish markets company stock vs industry index and market index behave in them same way.

Table 1 illustrates descriptive statistics of return of the series. As evident from Table 1, returns of all series are negatively skewed and the kurthosis is much higher than 3 for all the cases. This is indicative of the deviation of series from the normal distribution which is also supported with Jarque-Bera statistics. Further the stationarity of the variables has been examined using Augmented Dickey-Fuller (ADF) unit root test. The null hypothesis of the unit root is rejected for all return series. Returns of all series are calculated by taking the first differences of the logarithm of the two successive prices i.e. $r_{t}=$ $\log \left(P_{t}-P_{t-1}\right)$ which are RCRUDE, RSPX, RSPXSMM, RXU100, RXUSIN, RNUCOR, RAKSTEEL, RUSSTEEL, and REREGLI. Time 
series graphs of the returns have been illustrated which exhibits vividly how volatility has varied in the last one year while we experienced many twitter cases of Trump in Figure 2. It is visible that industry indices (SPXSMM and XUSIN) experience more volatility clustering than the whole market indices (SPX and XU100).

Table 1:

Descriptive statistics of Return Series

\begin{tabular}{|c|c|c|c|c|c|c|c|c|c|}
\hline & RAKSTEEL & RCRUDE & RNUCOR & RSPX & RSPXSMM & RUSSTEEL & REREGLI & RXU100 & RXUSIN \\
\hline Mean & 0.000 & 0.000 & 0.000 & 0.000 & 0.000 & 0.000 & 0.000 & 0.000 & 0.000 \\
\hline Median & 0.000 & 0.000 & 0.000 & 0.000 & 0.000 & 0.000 & 0.000 & 0.000 & 0.000 \\
\hline Maximum & 0.068 & 0.092 & 0.040 & 0.020 & 0.033 & 0.085 & 0.031 & 0.022 & 0.012 \\
\hline Minimum & -0.150 & -0.062 & -0.050 & -0.021 & -0.035 & -0.088 & -0.031 & -0.024 & -0.029 \\
\hline Std. Dev. & 0.011 & 0.006 & 0.005 & 0.003 & 0.004 & 0.009 & 0.005 & 0.003 & 0.003 \\
\hline Skewness & -0.817 & 0.522 & -0.392 & -0.454 & -0.202 & -0.699 & 0.118 & -0.455 & -1.057 \\
\hline Kurtosis & 17.66 & 29.41 & 16.89 & 14.03 & 12.67 & 21.63 & 7.75 & 10.23 & 12.55 \\
\hline Jarque-Bera & 32064.92 & 103007 & 28553.25 & 18056.09 & 13813.9 & 51473.64 & 4207.938 & 9896.132 & 17829.99 \\
\hline Probability & 0.0000 & 0.0000 & 0.0000 & 0.0000 & 0.0000 & 0.0000 & 0.0000 & 0.0000 & 0.0000 \\
\hline ADF Test (Level) & $\begin{array}{l}-61.970 \\
{[0.0001]}\end{array}$ & $\begin{array}{c}-59.081 \\
{[0.0001]}\end{array}$ & $\begin{array}{l}-62.987 \\
{[0.0001]}\end{array}$ & $\begin{array}{l}-57.762 \\
{[0.0001]}\end{array}$ & $\begin{array}{l}-59.128 \\
{[0.0001]}\end{array}$ & $\begin{array}{l}-60.428 \\
{[0.0001]}\end{array}$ & $\begin{array}{l}-65.254 \\
{[0.0001]}\end{array}$ & $\begin{array}{l}-64.594 \\
{[0.0001]}\end{array}$ & $\begin{array}{l}-65.2365 \\
{[0.0001]}\end{array}$ \\
\hline
\end{tabular}

Notes: between parantheses: p-values. The number of observations is 3539 for RAKSTEEL, RCRUDE, RNUCOR, RSPX RSPXSMM, RUSSTEEL and 4417 for REREGLI, RXUSIN and RXU100. JB are the empirical statistics for Jarque-Bera test for normality based on skewness and excess kurtosis.

ADF Test refers to Augemented Dickey Fuller test for the presence of unit root for log differences (returns).

Dummy variables for trade war and monetary policy and FED decision news are created based on 584 individual news about trade war and 88 individual news for monetary policy and FED by matching them semi-hourly asset data one by one. Whenever there is news in the market about trade wars and monetary policy the dummy variables takes the value of " 1 " and otherwise " 0 ". With the interaction dummy variables we test the impact of cross-asset returns on both return and volatilities of steel industry companies when news about trade war and monetary policy is spread out in the market.

Figure 2: Graphs of Returns of Selected Companies and Market Indices
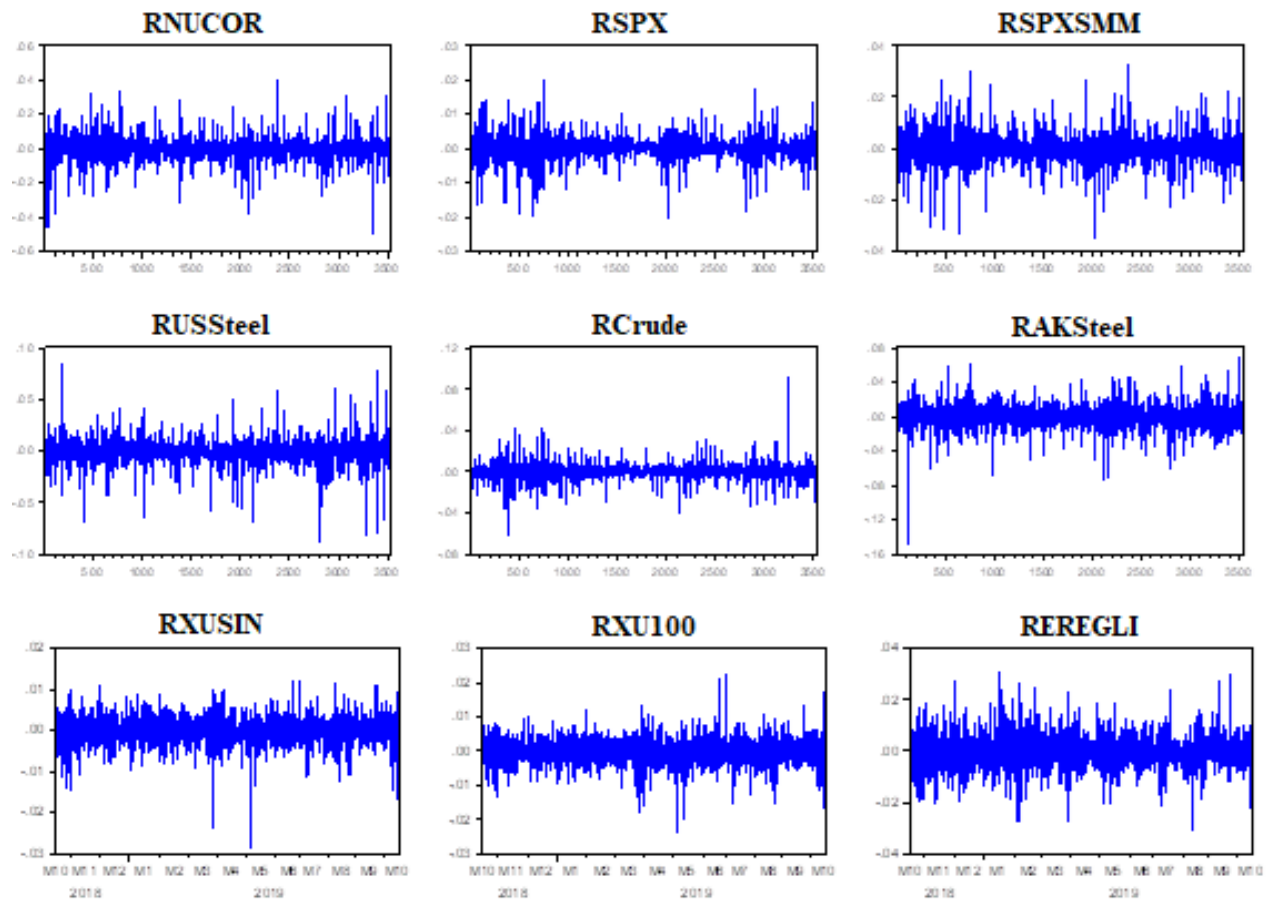


\section{EMPIRICAL RESULTS}

Having performed unit root tests next step is to run different versions of GARCH models for major steel companies in US, S\&P 500 index and Ereğli stocks to test the news spillover impact in Turkish financial markets. In Table 2-Panel A, the results of multivariate GARCH models indicate that coefficients of interaction variables are all positive and significant at \%1 significance level in the mean equation. For the variance equation the interaction variables are still valid and significant at $\% 1$ level however their volatility varies due to the related asset. We will analyze Panel B results one by one for the selected companies. Results from GARCH models delineate that whenever there is a news about trade wars and FED interest rate decisions or monetary policy of FED in the markets, it is expected to increase the return of AK Steel, US Steel, Nucor and S\&P 500. For Ereğli only trade war news seems valid for the same hypothesis.

In Table 3-Panel A results of the multivariate EGARCH models also indicate the same results with Table 2-Panel A with only Ereğli is an exception. Only the sign of tradewar*rereğli interaction term changes in EGARCH models for the mean equations. However, more significant difference is observed in the variance equation in which the impact of interaction terms significantly increased in EGARCH models.

Panel B of Table 2 summarizes the results of GARCH models for the selected companies and S\&P 500 index. The sum of the coefficients of the lagged squared error and the lagged conditional variance are close to unity (0.99) for S\&P 500 index implying that shocks to conditional variance are highly persistent. For AK Steel, US Steel, Nucor and Ereğli the impact of persistency is lower compared to S\&P 500. Interaction terms have a volatility reducing impact for AK Steel, Nucor, and S\&P 500 index while for US Steel and Ereğli the interaction terms have a positive impact on volatility.

Figure 3: News Impact Curves of Selected Assets
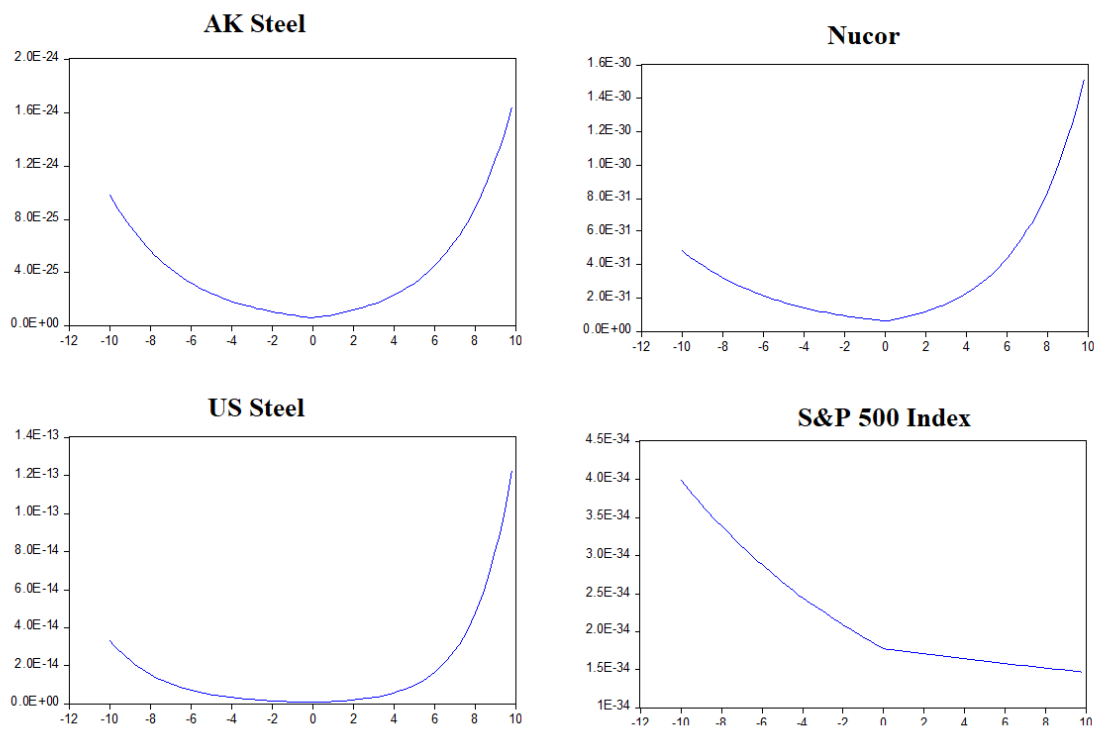

Ereğli

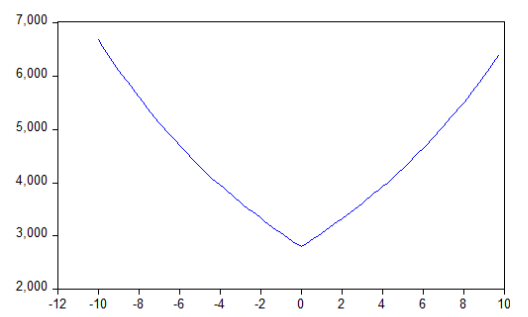

Hence EGARCH models are important for us to obtain News Impact Curves (NICs) and test the leverage effect (Figure 3). Any news increases volatility however if the news is "good" volatility increases along the right side of the curve. If the news is 
"bad" volatility increases along the left side of the curve. Since for AK Steel, US Steel and Nucor right side of the NICs is steeper than the left side, a positive $\varepsilon_{t}$ shock will have a bigger effect on volatility than a negative shock of the same magnitude.

For Ereğli stocks the NIC is nearly symmetric which suggests that any news good or bad has the same impact on the volatility of returns. Finally, S\&P 500 index, since the left side of the curve is steeper than the right side, a negative $\varepsilon_{t}$ shock will have bigger effect on volatility than a negative shock of the same magnitude which is quite consistent with an approach that S\&P 500 index represents the whole financial markets.

Table 2:

GARCH Models

\begin{tabular}{|c|c|c|c|c|c|}
\hline $\begin{array}{c}\text { Panel A-Mean Equation } \\
\text { Parameters }\end{array}$ & GARCH (AK Steel) & GARCH (US Steel) & GARCH (Nucor) & GARCH (Ereğli) & GARCH (SPX) \\
\hline $\mathrm{c}$ & $N A^{*}$ & $\mathrm{NA}^{*}$ & $N A^{*}$ & $N A^{*}$ & $0.0000[0.00143]$ \\
\hline russteel & $0.3265[0.0000]$ & & $0.1082[0.0000]$ & & \\
\hline rspxsmm & $1.1332[0.0000]$ & $1.0467[0.0000]$ & $0.6918[0.0000]$ & & \\
\hline tradewarraksteel & $0.4872[0.0000]$ & & & & \\
\hline monetary*raksteel & $0.4798[0.0000]$ & & & & \\
\hline rxusin & & & & $1.2819[0.0000]$ & \\
\hline rcrude & & & $0.0418[0.0000]$ & & $0.1240[0.0000]$ \\
\hline tradewar*rnucor & & & $0.2578[0.0001]$ & & \\
\hline monetary ${ }^{\star}$ rnucor & & & $0.2968[0.0000]$ & & \\
\hline raksteel & & $0.1979[0.0000]$ & & & \\
\hline tradewar*russteel & & $0.4476[0.0000]$ & & & \\
\hline monetary*russteel & & $0.2923[0.0000]$ & & & \\
\hline monetary*rpsx & & & & & $0.7063[0.0000]$ \\
\hline tradewar*rspx & & & & & $0.8857[0.0000]$ \\
\hline tradewar*reregli & & & & $-0.6017[0.0000]$ & \\
\hline $\begin{array}{c}\text { Panel B-Variance } \\
\text { Equation }\end{array}$ & GARCH (AK Steel) & GARCH (US Steel) & GARCH (Nucor) & GARCH (Ereğli) & GARCH (SPX) \\
\hline$\omega$ & $0.0000[0.0006]$ & $0.0000[0.0000]$ & $0.0000[0.0000]$ & $0.0000[0.0000]$ & $0.0000[0.0000]$ \\
\hline$\alpha$ & $0.0121[0.0344]$ & $0.2473[0.0010]$ & $0.1343[0.0000]$ & $0.0711[0.0000]$ & $0.0178[0.0000]$ \\
\hline$\beta$ & $0.5798[0.0000]$ & $0.0726[0.0000]$ & $0.1945[0.0000]$ & $0.5549[0.0000]$ & $0.9791[0.0000]$ \\
\hline raksteel & $-0.0000[0.0000]$ & $0.0066[0.0000]$ & & & \\
\hline monetary ${ }^{\star}$ raksteel & $-0.0032[0.0000]$ & & & & \\
\hline tradewar ${ }^{\star}$ raksteel & $-0.0010[0.0031]$ & & & & \\
\hline rcrude & & & $0.0000[0.0000]$ & & \\
\hline rnucor & & & $0.0000[0.0000]$ & & \\
\hline tradewar*rnucor & & & $-0.0002[0.0000]$ & & \\
\hline rspxsmm & & & $-0.0000[0.0000]$ & & \\
\hline russteel & & $-0.0004[0.0013]$ & & & \\
\hline tradewar*russteel & & $0.0001[0.0000]$ & & & \\
\hline monetary*rpsx & & & & & $-0.0003[0.0000]$ \\
\hline tradewarrspx & & & & & $-0.0001[0.0000]$ \\
\hline monetary*reregli & & & & $0.0008[0.0000]$ & \\
\hline tradewar*reregli & & & & $0.0006[0.0000]$ & \\
\hline rxusin & & & & $-0.0003[0.0000]$ & \\
\hline R2 & 0.5231 & 0.5829 & 0.6473 & 0.4902 & 0.2274 \\
\hline DW & 2.2490 & 2.0872 & 2.2845 & 1.9970 & 1.9318 \\
\hline
\end{tabular}

Notes: Between parantheses: p-values.

$\mathrm{NA}^{*}$ refers to the omitted constants in the models since they were statistically insignificant for the related models.

Also when we compare $\mathrm{R}^{2}$ values, it is clear that the logic of our GARCH models for selected companies are much more successful than S\&P 500 index referring that specific news such as trade wars, FED decisions and monetary policy are more significant for individual company stocks.

As a result, we can conclude that tweets and specific news about trade wars and monetary policy as well as FED decisions have an impact on the volatility of steel companies. Since those new shocks are created mostly by the actors who have the market power, their impact should be analyzed more carefully from a market speculation perspective. 
Table 3:

EGARCH Models

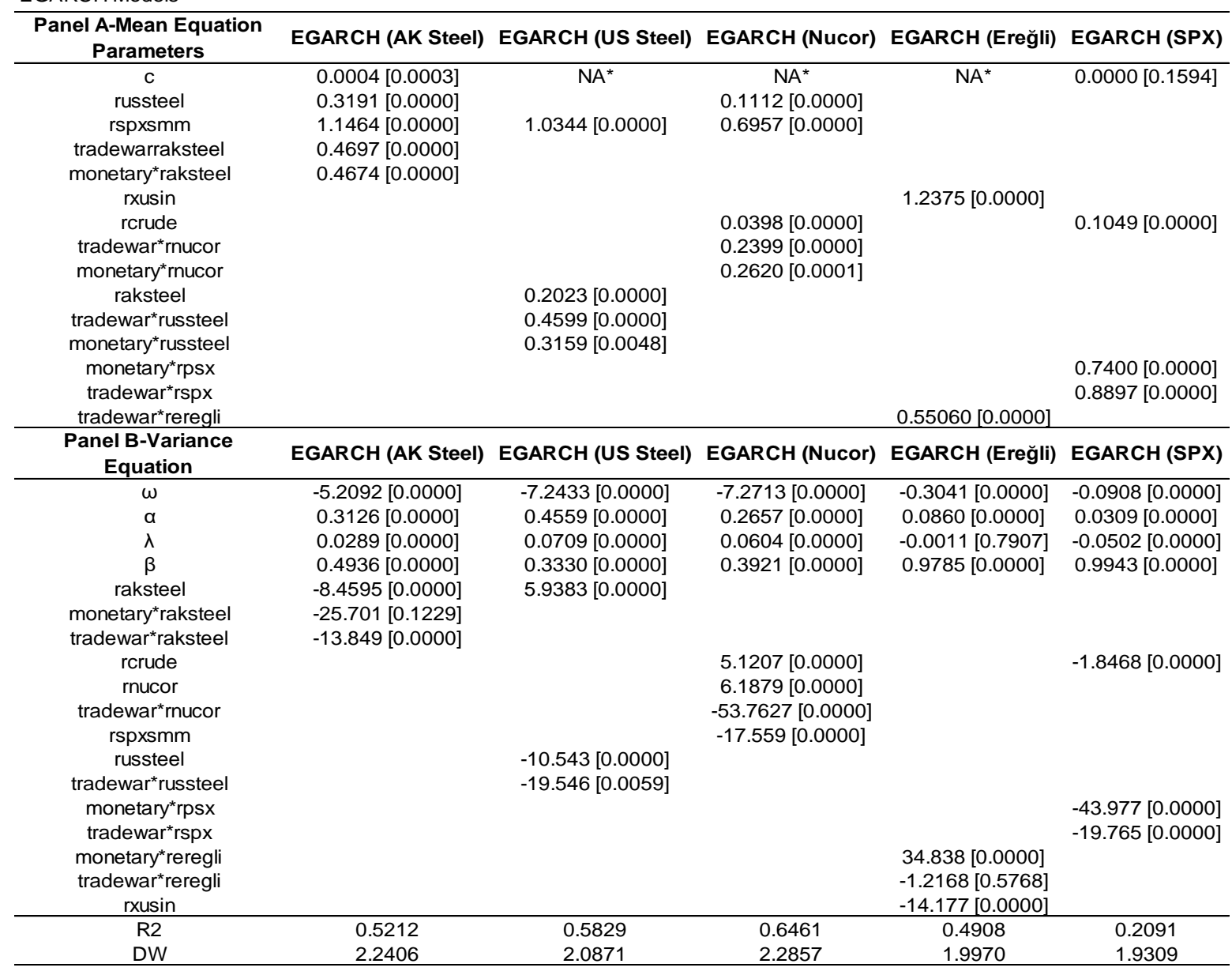

Notes: Between parantheses: p-values.

$\mathrm{NA}^{*}$ refers to the omitted constants in the models since they were statistically insignificant for the related models.

\section{CONCLUSION}

During his election campaign, Trump made several references to the US steel industry and vowed to protect US steel jobs, which are under threat due to higher imports. After Trump's election in 2016, we saw a rally in equity markets. Trump was expected to protect steel companies from the onslaught of steel imports. Recent trade war news and monetary policy news mainly including Trump and Powell (and/or China) conflicts brought a new dimension to the news effect approach in volatility modeling. As one the major market makers, Trump's direct messages to the market via Twitter and such, about sanctions, interest rates and monetary policy creates "Black Noise" in financial markets. Even in a durable production industry like steel sector this leads to speculation. Although there are recent studies which claim that Trump's tweets carry transitory impact, but it's very short-term and doesn't appear to last, Analysts at JPMorgan Chase have created an index ${ }^{7}$ to gauge the impact of Donald Trump's tweets on US interest rates. In order to test this impact more efficiently our approach was to utilize high frequency semi-hourly data and related news but matching them exactly on the time they are announced.

For further research papers testing the speculation strength of such tweet can be a beneficial topic for the other researchers.

\footnotetext{
${ }^{7}$ Analysts at JPMorgan Chase have created an index to gauge the impact of Donald Trump's tweets on US interest rates
} 


\section{REFERENCES}

Cappiello, L., Engle, Sheppard, K., (2006), Asymmetric Dynamics in the Correlations of Global Equity and Bond Returns, Journal of Financial Econometrics, Vol. 4, No. 4, pp. 537-572

Chen, X., Ghysels, E., (2010), News-Good or Bad-and Its Impact on Volatility Predictions over Multiple Horizons, The Society for Financial Studies, Oxford University Press.

Cove, S., College, R., and Sardy, M., (2019), How Presidential Tweets Affect Financial Markets

Fama, E. (1970. Efficient capital markets: A review of theory and empirical work, Journal of Finance, 25(2), 383-417

Forbes, K., J., and Rigobon, F. (2001), Measuring Contagion: Conceptual and Empirical Issues in International Financial Contagion (Eds) Claessens, S., and Forbes, K., New York: Springer, 43-66

Goldstein, J., and Martin, L., L., (2000), Legalization, trade liberalization, and domestic politics: A cautionary note, International Organization, 54(3), 603-632

Jensen, M., Nathan (2007), International institutions and market expectations: Stock price responses to the WTO ruling on the 2002 US steel tariffs, Springer Science+ Business Media, 2: 261-280

Kaminsky, G., L., Reinhart, C., M., Vegh, C., A., (2003), The unholy trinity of financial contagion, The Journal of Economic Perspectives, Vol. 17, No. 4 (Autumn, 2003), pp. 51-74

King, M., A, Wadhwani, S., (1990), Transmission of volatility between stock markets, The Review of Financial Studies, 57(2), 769-799

Kodres, L., E., and Pritsker, M., (1998), A rational expectations model of financial contagion, Finance and Economics Discussion Series 199848, Board of Governors of the Federal Reserve System (US).

Lo, A. W., and MacKinlay, A., C., (1999), A non-random walk down wall street, Princeton, NJ: Princeton University Press

M. Guidolin et al. (2019), Cross-asset contagion in the financial crisis: A Bayesian timevarying parameter approach,Journal of Financial Markets 45 (2019) 83-114

Nelson, B., D, (1991), Conditional Heteroskedasticity in Asset Returns: A New Approach, Econometrica, Vol. 59, No. 2., pp. 347-370.

Sensier, M., Van Dijk, D., (2004). Testing for volatility changes in US macroeconomic time series, The Review of Economics and Statistics, 86 (3), 833-839

Stock, J.H., Watson, M.W., (1996). Evidence on structural instability in macroeconomic time series relations, Journal of Business \& Economic Statistics, 14 (1), 11-30.

Tafti, A., Zotti, R., Jank, W., (2016), Real-Time Diffusion of Information on Twitter and the Financial Markets, PLos ONE, Vol. 11(8)

https://m.economictimes.com/markets/stocks/news/volfefe-index-to-track-trump-tweet-impact/articleshow/71059008.cms 